\title{
Heath care utilization, access, and advocacy
}

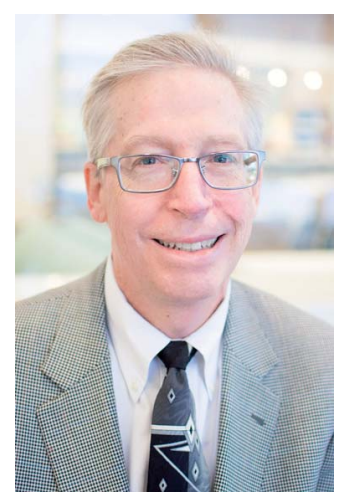

$\mathrm{N}$

eurologic diseases rarely occur in isolation. Clinical practitioners need to consider possible comorbidities and their effect on disease management when treating their patients. Lukmanji et al. (p. 344) review online tools for patients with neurologic diseases and depression and advocate for the development of high-quality, evidence-based online tools. Xu et al. (p. 324) use ENCHANTED trial data to examine early seizures after thrombolysis for acute ischemic stroke. Campiglio et al. (p. 296) use retrospective data to evaluate the utility of 48 hours of observation and a follow-up head CT in patients with mild brain injury taking anticoagulants. In the accompanying editorial, Nearing and Tsao (p. 280) observe that "more specific guidelines addressing subpopulations experiencing mTBI in order to decide length of observation, avoid unnecessary hospitalization, and relieve economic burden" are warranted.

Korn et al. (p. 283) report on a multicenter noncontrolled trial of virtual visits for Parkinson disease. Elrashidi et al. (p. 306) describe the effect of an integrated community neurology model on health care utilization, diagnostic testing, and access. Daniel Foster (p. 372) argues that transportation policy and health policy are interrelated and encourages neurologists to advocate for safe, healthy transportation options for all people, their patients first and foremost. Our Practice Current series explores the topic "How do you treat epilepsy in pregnancy?" Commentary by Ilena George (p. 363) provides a brief overview of the topic and commentary from 3 global experts. Go online to participate in our active surveys and explore survey results on our interactive maps for each topic.

As always, we welcome your feedback and invite suggestions for improvement.
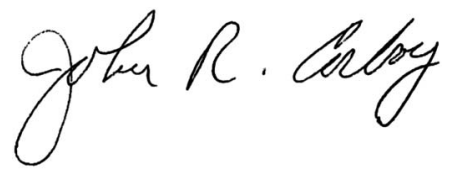

John R. Corboy, MD, FAAN 


\section{Neurology ${ }^{\circ}$ Clinical Practice}

Heath care utilization, access, and advocacy

Neurol Clin Pract 2017;7;279

DOI 10.1212/CPJ.0000000000000386

This information is current as of August 14, 2017

Updated Information \&

Services

Permissions \& Licensing

Reprints including high resolution figures, can be found at:

http://cp.neurology.org/content/7/4/279.full.html

Information about reproducing this article in parts (figures,tables) or in its entirety can be found online at:

http://cp.neurology.org/misc/about.xhtml\#permissions

Information about ordering reprints can be found online:

http://cp.neurology.org/misc/addir.xhtml\#reprintsus

Neurol Clin Pract is an official journal of the American Academy of Neurology. Published continuously since 2011, it is now a bimonthly with 6 issues per year. Copyright ( 92017 American Academy of Neurology. All rights reserved. Print ISSN: 2163-0402. Online ISSN: 2163-0933.

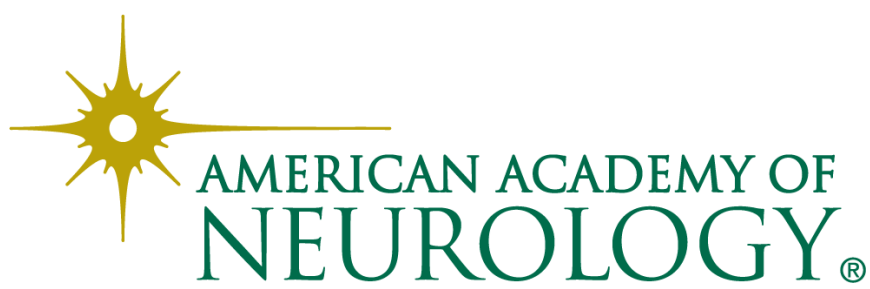

